\title{
Comparison of two mammalian surveys made with camera traps in southeastern Brazil, focusing the abundance of wild mammals and domestic dogs
}

\author{
Carvalho, WD. ${ }^{a, b *}$, Adania, $C H .^{b}$ and Esbérard, CEL. ${ }^{a}$ \\ anstituto de Biologia, Universidade Federal Rural do Rio de Janeiro - UFRRJ, Antiga estrada Rio-São Paulo, \\ Km 47, CP 74507, CEP 23890-000, Seropédica, RJ, Brazil \\ bAssociação Mata Ciliar, Av. Emílio Antonon, 1000, CEP 13212-010, Jundiaí, SP, Brazil \\ *e-mail: wilruoca@hotmail.com \\ Received September 22, 2011 - Accepted March 15, 2012 - Distributed February 28, 2013 \\ (With 4 figures)
}

\begin{abstract}
Sampling allows assessing the impact of human activities on mammal communities. It is also possible to assess the accuracy of different sampling methods, especially when the sampling effort is similar. The present study aimed at comparing two mammalian surveys carried out over a three-year interval, in terms of sampling effort, capture success, abundance of domestic dogs, impact of human activities, and relative biomass using camera traps, in the Serra do Japi Biological Reserve and surroundings, located in Jundiaí, state of São Paulo, southeastern Brazil. The total richness recorded was 13 species, one domestic and 12 wild mammals. Sampling effort in both surveys was similar, but capture success and number of captures differed. The abundance of wild mammals and dogs did also differ between surveys. There was a highly significant correlation between abundance of wild mammals and capture effort for the survey performed in 2006/2007, but not for the survey performed in 2009/2010. The difference between samples may be related to human disturbance, since the number of domestic mammals photographed was higher in the second survey, three years after the first survey. Despite being a reserve, the area is still under pressure from urbanization, biological invasion, environmental degradation, and hunting, which may reduce the abundance of wild mammals.
\end{abstract}

Keywords: survey, diversity, domestic animals, methods, nature reserves.

\section{Comparação entre duas amostragens de mamíferos feitas com armadilhas fotográficas no sudeste do Brasil, com foco na abundância de mamíferos silvestres e cães domésticos}

\section{Resumo}

Uma das formas de avaliar o impacto das atividades humanas nas comunidades de mamíferos e ter maior conhecimento e acurácia sobre o método utilizado é realizar amostragens, proporcionando a comparação do método, principalmente quando o esforço amostral é semelhante. O presente estudo visou a comparar dois levantamentos de mamíferos realizados na mesma área com três anos de intervalo, quanto aos seguintes aspectos: esforço amostral, sucesso de captura, abundância de cães domésticos, presença de atividades humanas e biomassa relativa das espécies. A riqueza total obtida nos dois períodos de amostragem foi de 13 espécies, sendo 12 espécies selvagens e uma de animal doméstico. $\mathrm{O}$ esforço de amostragem para as duas pesquisas foi semelhante, porém o sucesso de captura foi diferente, quando comparados entre si. A abundância de mamíferos selvagens e cães também mostrou diferenças entre os dois períodos. A correlação entre a abundância de mamíferos selvagens e o esforço de captura provou ser altamente significativa para a amostragem realizada em 2006/2007, mas não foi significativa para a realizada em 2009/2010. A diferença entre as amostras pode estar ligada à perturbação humana nesse ambiente, já que o número de animais domésticos fotografados foi maior após três anos de amostragem. Apesar de ser uma área de conservação, também está sujeita a pressões, como especulação imobiliária, invasões, destruição e caça, o que pode estar diminuindo a abundância das espécies selvagens listadas neste trabalho.

Palavras-chave: levantamento, diversidade, animais domésticos, métodos, unidades de conservação. 


\section{Introduction}

Several species of wild mammals are seen as game or pets, and so they are hunted in their natural habitats (Mendes, 2004). Fragmentation, road construction, trails, and proximity to urban areas can facilitate the access of hunters. Only $2 \%$ of the Atlantic Forest is under legal protection (Myers et al., 2000). The main goal of the extant reserves is to protect biodiversity. Nevertheless, hunting and illegal extraction of natural resources still occur in these areas (Olmos et al., 2002). Legal protection against deforestation does not preclude introduction of exotic species, which has caused severe impacts on native species (Elton, 1972; Tabarelli et al., 2005).

Natural ecosystems have undergone all kinds of impact caused by feral and exotic species, such as dogs, cats, horses, pigs, and many other vertebrates (Galetti and Sazima, 2006). Pets can also affect the native fauna in several ways, including increase in predation (Kruuk and Snell, 1981; Barnett and Rudd, 1983; Lepczyk et al., 2004; Kays and Dewan, 2004) and disease transmission (Anderson et al., 2006; Hammer et al., 2004). Galetti and Sazima (2006) stated that the high impact of feral dogs on some mammals is probably the major cause of extinction in their study area (Santa Genebra Forest, southeastern Brazil). This effect was observed for species such as Cuniculis paca (Linnaeus, 1766), Mazama guazoubira, (G. Fischer, 1814), and Dasyprocta azarae Lichtenstein, 1823.

Mammal sampling serves many purposes: diversity estimation, comparison of sites, as a basis to refine species distribution maps, and evaluation of the impact of human activities on ecological communities (Tobler et al., 2008). The use of non-invasive and standardized methods, such as camera traps, can provide data on presence, abundance and movements of exotic mammals and their relationship with human activities. Despite the excellent results obtained with camera traps in inventories and analysis of richness and abundance of non-volant mammals (Voss and Emmons, 1996; Trolle, 2003; Lyra-Jorge et al., 2008; Tobler et al., 2008; Silva and Passamani, 2009), studies comparing sampling efficiency between devices, especially in the same site, are still scarce. O'Brien (2008) stated that the next challenge for researchers will be the elaboration of projects about the potential use of camera traps in biodiversity monitoring. Some authors state that a standardised method allows simple comparisons between sampling sites and inventories (Silver et al., 2004; Karanth and Nichols, 1998; Kelly et al., 2008; O’Brien, 2008; Tobler et al., 2008).

The present study aimed at comparing two mammalian surveys carried out with camera traps in the same area in similar periods of the year with a three year interval, comparing sampling effort, capture success, abundance of domestic dogs, impact of human activities, and relative biomass.

\section{Material and Methods}

The present study was carried out in Serra do Japi Biological Reserve (hereafter Serra do Japi) and surroundings.
Serra do Japi is located in the municipality of Jundiaí, state of São Paulo, southeastern Brazil (23 $12^{\prime}-23^{\circ} 21^{\prime}$ $\mathrm{S}$ and $\left.46^{\circ} 30^{\prime}-47^{\circ} 05^{\prime} \mathrm{W}\right)$, in the Atlantic Plateau, and comprises an area of 2,071.2 ha (Ponçano et al., 1981) (Figure 1). Although Serra do Japi is one of the last large areas of continuous forest in the state of São Paulo, which covers ca. $350 \mathrm{~km}^{2}$, only $20.7 \mathrm{~km}^{2}$ of the state is under full protection. Because Serra do Japi is located near three major urban and industrial centres (São Paulo, Jundiaí and Campinas), it undergoes intense anthropic pressure and may be totally devastated if not effectively protected (Morellato and Leitão-Filho, 1992).

Serra do Japi has a mountain landscape, with altitudes ranging between 700 and 1,300 m a.s.l. (Santoro and Machado-Junior, 1992). Two climate types occur in the area: humid temperate with warm summer (Cfa) and humid temperate with mild summer (Cfb) (Setzer, 1966) and a hot and rainy season and a dry and cold season (Pinto, 1992). The average annual temperature varies from $15.7^{\circ} \mathrm{C}$ to $19.2^{\circ} \mathrm{C}$, depending on the altitude. According to Veloso and Góes-Filho (1992) and Brasil (1992), the vegetation of this region is classified as semi-deciduous seasonal forest. There is a predominance of mesophilic semi-deciduous forests and altitudinal mesophilic semi-deciduous forests, with sparse rocky plateaus (Leitão-Filho, 1992). In the areas with altitudes exceeding 1,040 $\mathrm{m}$ a.s.l., the vegetation is classified as altitudinal mesophilic semi-deciduous forests (Caselli and Setz, 2011).

Two surveys were conducted in this reserve: (i) from July 2006 to February 2007, using seven camera traps placed in seven sampling sites on trails that were already established in Serra do Japi; (ii) from July2009 to February 2010, using the same seven camera traps plus three new ones, arranged in ten sampling sites on trails in the same area.

The camera traps $\left(\right.$ Trapa Camera ${ }^{\circledR}$ ) are activated by movement through a passive infrared beam, shooting a $35 \mathrm{~mm}$ analog camera (Canon ${ }^{\circledR}$ model BF35). Sampling sites were $1 \mathrm{~km}$ away from each other, and camera traps were set up at $0.4 \mathrm{~m}$ above the ground and perpendicular to the trails. The cameras were programmed to remain turned on $24 \mathrm{~h}$ a day and to have a minimum interval of $60 \mathrm{~s}$ between shots. Camera traps remained in the field six days a week and were removed to avoid damage on Saturdays, when there are more visits in the area.

Aiming at improving data independence, photos of the same species in the same site within an interval shorter than 60 min were discarded, because some species (mainly the white-lipped peccary and the collared peccary) can remain for a long time in front of a camera (Tobler et al., 2008). The classification of mammalian species into small, medium, and large was based on average body mass data obtained from Nowak (1999).

Sampling efficiency was compared using species accumulation curves (Esbérard and Bergallo, 2008). Sampling effort (expressed as camera.h) was based and modified Srbek-Araujo and Chiarello (2005), whereas frequency of occurrence (number of captures of a species/total number 

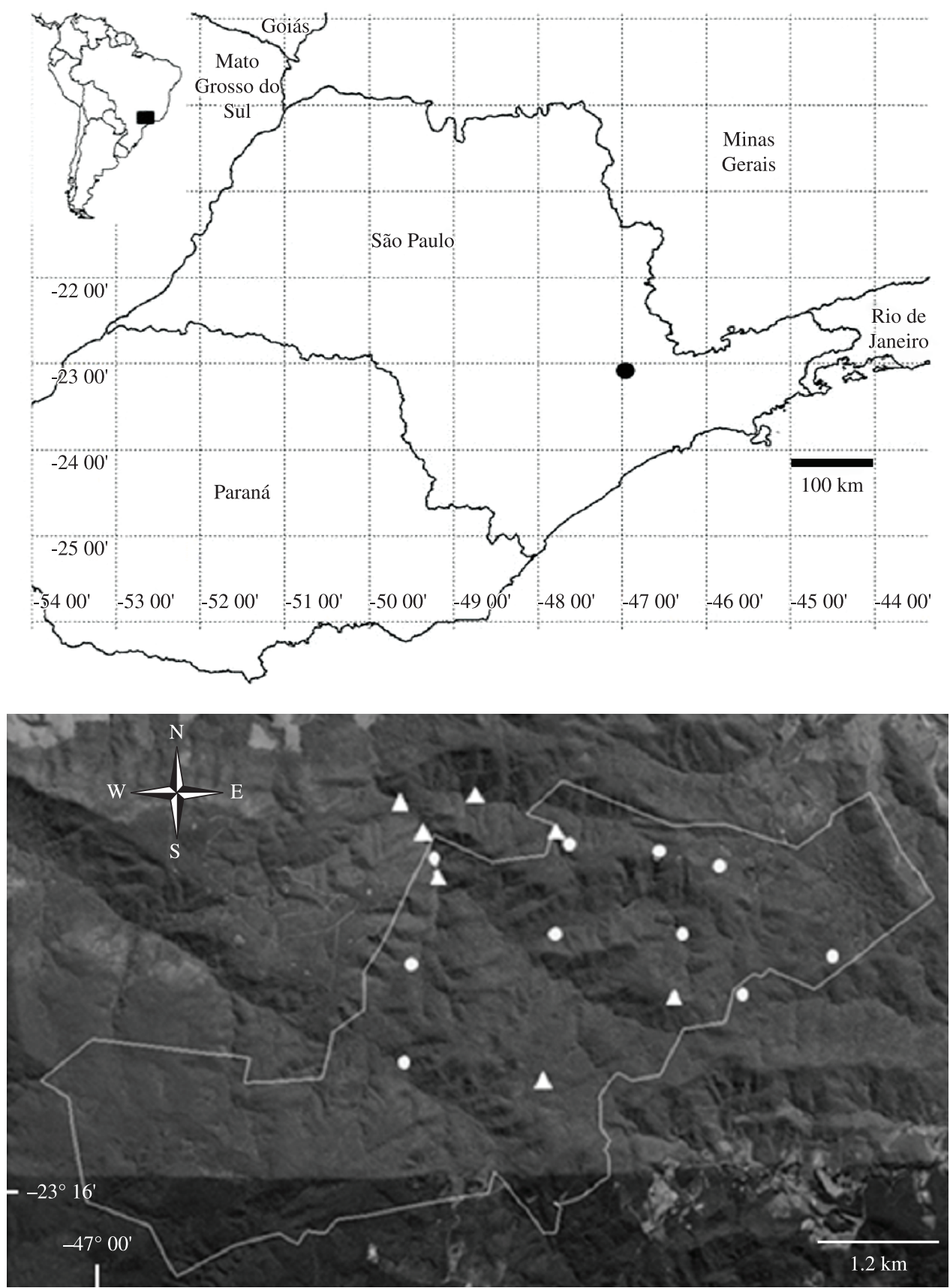

Figure 1. Location of Serra do Japi. The white line shows the boundaries of Serra do Japi Biological Reserve. White triangles represent the sites sampled in the first survey and white circles represent the sites sampled in the second survey.

of captures, expressed as percentage) followed Prado et al. (2008), and relative proportion followed Tobler et al. (2008). The Mann Whitney test was used to test for differences in capture success (number of records/sampling effort, expressed as percentage), sampling effort (total number of hours when all camera traps in the site remained on), and number of captures (number of valid and independent records) between surveys. The chi-square test was used to test differences in the abundance of species and impacts between surveys, being that images of visitors, cyclists, motorcyclists and cars were grouped as all resulted in human impacts. The Spearman correlation was used to test for a relationship between average body mass and number of records of a species. Logarithmised abundance values were used to classify species by decreasing abundance. The relationship between relative proportions of each species 
in each survey was tested with a Spearman correlation. We also calculated a linear regression between capture effort and species abundance. All statistical tests were made in Past $^{\circledR} 2.01$ and Statistica ${ }^{\circledR}$ 8.0.

\section{Results}

The total richness recorded was 13 species: one domestic and 12 wild mammals of 13 genera, nine families, and six orders (Table 1). Didelphis aurita (Wied-Neuwied, 1826), N. nasua (Linnaeus, 1766), E. barbara (Linnaeus, 1758), and C. paca (Linnaeus, 1766) were exclusive to the first survey, whereas $C$. thous (Linnaeus, 1766) was the only exclusive species in the second survey. D. aurita, D. novemcinctus Linnaeus, 1758, Mazama gouazoubira (g. Fischer, 1814), C. paca, S. brasiliensis (Linnaeus, 1758), and L. europaeus (Pallas, 1778) were also recorded and are considered as game species (Araújo et al., 2008; Travassos, 2011). The most abundant species in the first survey were S. brasiliensis (34.56\% of the species) and D. aurita $(19.75 \%)$, and in the second survey were the species Canis lupus familiaris Linnaeus, 1758 (48.71\%) and L. pardalis (Linnaeus, 1758) (17.94\%) (Figure 2).

The species accumulation curves did not stabilise in any of the surveys, but they seemed to be representative of local richness (Figure 4). The total sampling effort was 15,108 camera.h; 8,448 in the first survey and 6,660 in the second survey. Out of 1,944 photos taken during the two surveys, 636 photos were obtained in the first and 1,308 in the second survey. Capture success was $1 \%$ in the first survey and $0.63 \%$ in the second. Sampling effort was similar $(U=21 ; \mathrm{p}<0.18)$ in the two surveys, but capture success $(U=2 ; p<0.01)$ and number of captures $(U=12$;

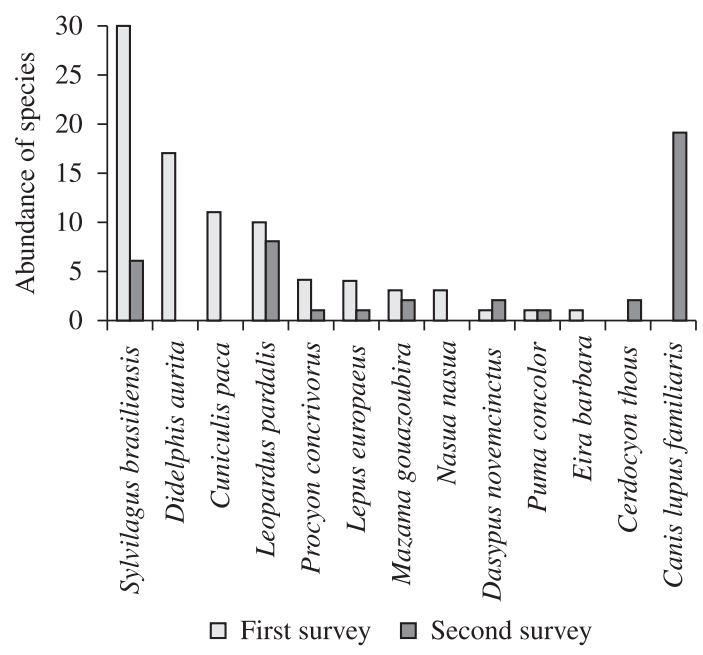

Figure 2. Abundance ranks of species.

Table 1. Species, frequency of occurrence, and local vernacular names of mammals photographed in Serra do Japi in the first and second surveys (2006/2007 and 2009/2010, respectively).

\begin{tabular}{|c|c|c|c|c|}
\hline \multirow{2}{*}{$\begin{array}{l}\text { ORDER } \\
\text { Family }\end{array}$} & \multirow[t]{2}{*}{ Species } & \multicolumn{2}{|c|}{$\begin{array}{c}\text { Abundance } \\
\text { (frequency of occurrence) }\end{array}$} & \multirow{2}{*}{$\begin{array}{c}\text { Local Vernacular } \\
\text { Name }\end{array}$} \\
\hline & & $2006 / 2007$ & $2009 / 2010$ & \\
\hline \multicolumn{5}{|l|}{ DIDELPHIMORPHIA } \\
\hline Family Didelphidae & Didelphis aurita Wied-Neuwied, 1826 & $17(20)$ & - & $\begin{array}{l}\text { gambá-de-orelha- } \\
\text { preta }\end{array}$ \\
\hline \multicolumn{5}{|l|}{ CINGULATA } \\
\hline Family Dasypodidae & Dasypus novemcinctus Linnaeus, 1758 & $1(1.17)$ & $2(4.76)$ & tatu-galinha \\
\hline \multicolumn{5}{|l|}{ CARNIVORA } \\
\hline \multirow[t]{2}{*}{ Family Canidae } & Canis lupus familiaris Linnaeus, 1758 & - & $19(45.23)$ & cachorro-doméstico \\
\hline & Cerdocyon thous (Linnaeus, 1766) & - & $2(4.76)$ & cachorro do mato \\
\hline \multirow[t]{2}{*}{ Family Felidae } & Leopardus pardalis (Linnaeus, 1758) & $10(11.76)$ & $8(19.04)$ & jaguatirica \\
\hline & Puma concolor (Linnaeus, 1771) & $1(1.17)$ & $1(2.38)$ & onça-parda \\
\hline \multirow[t]{2}{*}{ Family Procyonidae } & $\begin{array}{l}\text { Procyon cancrivorus (G.[Baron] Cuvier, } \\
1798)\end{array}$ & $4(4.70)$ & $1(2.38)$ & mão pelada, \\
\hline & Nasua nasua (Linnaeus, 1766) & $3(3.52)$ & - & quati \\
\hline Family Mustelidae & Eira barbara (Linnaeus, 1758) & $1(1.17)$ & - & irara, papa-mel \\
\hline \multicolumn{5}{|l|}{ ARTIODACTYLA } \\
\hline Family Cervidae & Mazama gouazoubira (G. Fischer, 1814) & $3(3.52)$ & $2(4.76)$ & veado-catingueiro \\
\hline \multicolumn{5}{|l|}{ RODENTIA } \\
\hline Family Cuniculidae & Cuniculus paca (Linnaeus, 1766) & $11(12.94)$ & - & paca \\
\hline \multicolumn{5}{|l|}{ LAGOMORPHA } \\
\hline \multirow[t]{2}{*}{ Family Leporidae } & Sylvilagus brasiliensis (Linnaeus, 1758) & $30(35.29)$ & $6(14.28)$ & tapiti \\
\hline & Lepus europaeus (Pallas, 1778) & $4(4.70)$ & $1(2.38)$ & lebre européia \\
\hline
\end{tabular}


$\mathrm{p}<0.2)$ differed. The abundance of wild mammals did also differ between surveys $\left(x^{2}=113.5 ; \mathrm{p}<0.01\right)$. In the first survey 85 independent photos were taken, whereas only 42 were taken in the second survey. The abundance of domestic dogs differed between surveys, without records in the first survey and records of at least 19 dogs in the second survey.

The number of null shots differed between the first and second surveys $\left(\mathrm{x}^{2}=5.28 ; \mathrm{p}<0.02\right)$; with 456 null shots in the first and 1,139 in the second. The number of images of visitors, cyclists, motorcyclists, and cars did not differ between the first and second surveys $\left(x^{2}=0.80 ; p<0.37\right)$.

The correlation between the average body mass of each species and the number of captures was not significant $(r=-0,44 ; p=0.13)$. The linear regression between the abundance of wild mammals and capture effort was highly significant in the first survey (abundance $=0.013 *$ Sampling effort $\left.-4,25 ; \mathrm{r}=0,92 ; \mathrm{r}^{2}=0.85 ; \mathrm{p}<0.03\right)$ but not in the second $(r=-0,18 ; p<0.60)$ (Figure 3$)$. The correlation between relative proportion of species (capture success for each species) in the two surveys was not significant $(\mathrm{r}=-0,20 ; \mathrm{p}=0.49)$.

\section{Discussion}

The richness and abundance observed in the present study are similar to those reported in other studies, and the sampling effort can be considered as satisfactory according to Tobler et al. (2008). These authors reported that with a total effort of $90,720 \mathrm{~h}$, they obtained a total richness of 40 species, with 1,163 images of wild animals and a capture success of $1.23 \%$ in the first survey and $1.30 \%$ in the second. They estimated that between 9,600 and $12,000 \mathrm{~h}$ of camera trapping would be necessary to record most of the common species. Srbek-Araújo and Chiarello

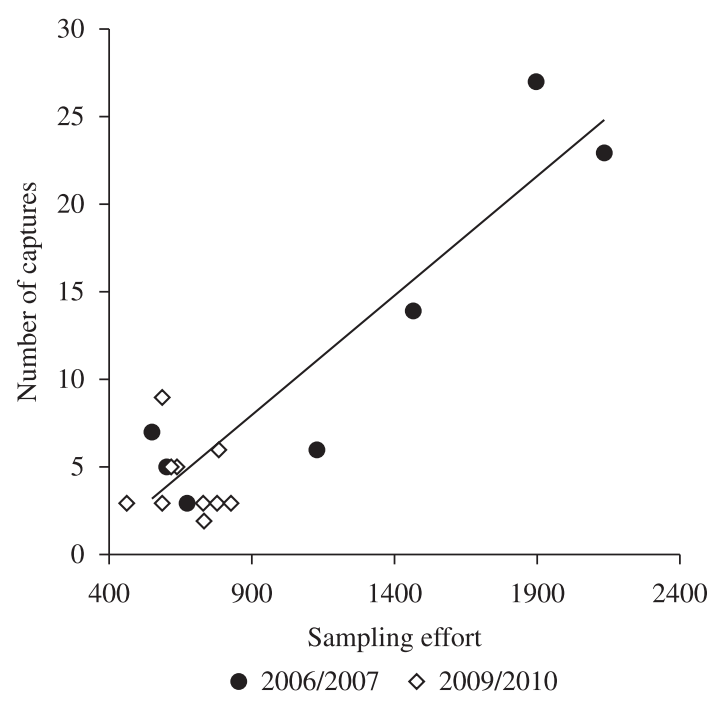

Figure 3. Relationship between abundance of wild mammals and sampling effort in each survey in Serra do Japi. Dots represent sampling sites.
(2005) photographed 21 species with 44,376 h of camera trapping in the Atlantic Forest. Alves and Andriolo (2005) recorded 10 species with 5,304 h of camera trapping in the Atlantic Forest, which represented a $58.01 \%$ success rate for custom made equipment and $46.05 \%$ for commercial equipment. Trolle and Kery (2003) recorded 23 species of large and medium mammals with only 12,096 h of camera trapping in the Brazilian Pantanal, and Silveira et al. (2003) recorded 23 species with 24,840 h of camera trapping in the Cerrado.

Other studies reported that body mass can affect recording by camera traps (Silveira et al., 2003; Kelly and Holub, 2008; Lyra-Jorge et al., 2008; Tobler et al., 2008), but this relationship was not observed in the present study. Results do not take into account that cameras are very sensitive to humidity, so their efficiency decreases with time, gradually lowering their capacity to sample especially small species (Cutler and Swann, 1999; Srbek-Araújo and Chiarello, 2007). There was a relationship between capture effort and species abundance in the first survey that was not observed in the second survey; this can be probably explained by the limitation of camera traps when used over a long time, though no difference was observed between camera traps between surveys. The number of null shots was significantly higher in the second survey; this difference could be related to the composition of vegetation and small animals or fallen trees in the sampling site (Trolle and Kery, 2003; Sberk-Araujo and Chiarello, 2005) or by wearing of the camera. In contrast, there was a decrease in the number of small mammals (Figure 2), although no variation in species composition was observed. These results do not corroborate the findings of Kelly (2008) using the raw data of Tobler et al. (2008).

Domestic dogs were not observed in the first survey, but 19 individuals were recorded in the second survey, in which they were the second most abundant species (48.71\%). Most records of domestic dogs were made inside Serra do Japi, contrary to findings by Odell and Knight (2001), Lacerda et al. (2009), Srbek-Araujo and Chiarello (2008), and Torres and Prado (2010), who observed higher frequencies in the edges of their study areas. These authors reported that high abundance of domestic dogs can be considered as an edge effect in fragmented areas. SrbekAraujo and Chiarello (2008) recorded 25 domestic dogs in Santa Lúcia Ecological Station, state of Espírito Santo, Brazil, with 51,408 h of camera trapping. Torres and Prado (2010) observed low density of domestic dogs compared to wildlife, in a study carried out in a fragmented area of Atlantic Forest in São Paulo, corroborating the results of the present study.

The presence of dogs may explain the lack of correlation between sampling effort and abundance of wild mammals. Galetti and Sazima (2006) found 46 carcasses of 12 different species killed by dogs in a study in the Santa Genebra Forest, after 44 months of sampling. Dogs can prey upon other mammals, mainly C. paca, M. gouazoubira, and D. azarae. Several authors showed that the presence of 

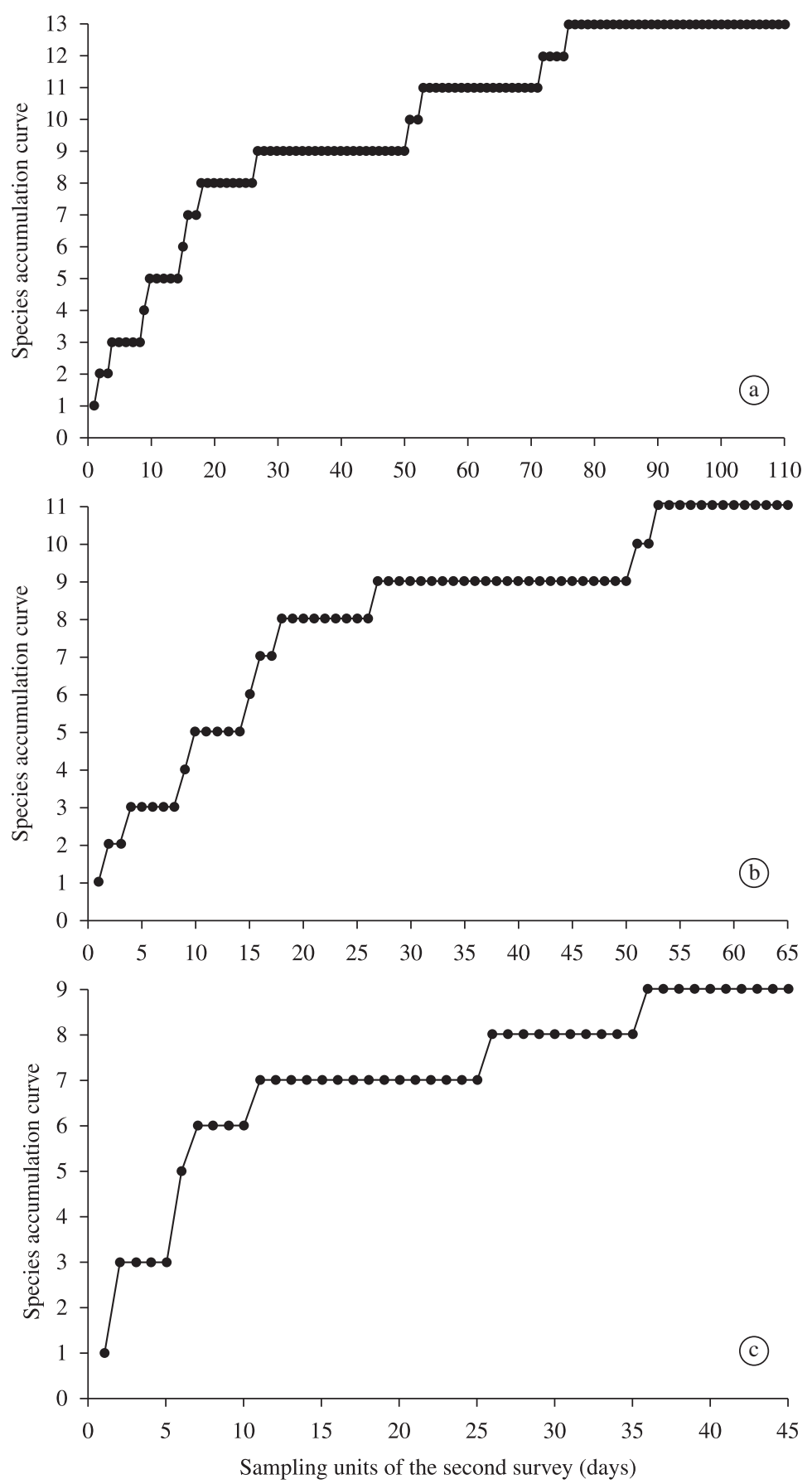

Figure 4. Total species accumulation curve for the survey with camera traps in Serra do Japi (a), species accumulation curve for the first survey (b), and species accumulation curve for the second survey (c).

dogs in forests can lead to the decline of native species, causing a negative environmental impact (Horowitz, 1992; Lacerda et al., 2009; Oliveira and Cavalcanti, 2002; Butler et al., 2004; Anderson et al., 2006; Galetti and Sazima, 2006; Srbek-Araújo and Chiarello, 2008).

Torres and Prado (2010) concluded that by increasing the awareness of residents in the surroundings of a forest is crucial to reduce the impacts of domestic dogs. In the present study the difference between surveys may be related to human disturbance in the study area, since the number of domestic animals recorded was higher three years after the first survey. The growth of nearby cities may have resulted in larger influx of visitors to the reserve and increase in the number of surrounding constructions. 
Acknowledgements - We are grateful to Serra do Japi Reserve for granting us a collecting permit and supporting the fieldwork, and to the Brazilian Centre for Conservation of Neotropical Cats. We also thank the field assistants R.M. Dias and M.S.M. Godoy, the Government and the Secretary of Planning and Environment of Jundiaí, and the Forest Rangers. J. M. Barbanti helped us identify deer species in camera trap photos. H.G. Bergallo, A. Pires, A.F.B. Araujo, L. Geise, D. Dias e E.C. Yoshida corrected and gave suggestions for completing this work. Tetra Pak ${ }^{\circledR}$ of Brazil provided us with part of the field material. W.D. Carvalho was granted a Master's fellowship by CAPES. C.E.L. Esbérard was granted research fellowships by CNPq. This study was carried out under the licenses SISBIO No. 19644-1/Proc. 3829564SISBIO 10356-1, 09/06/2007 IBAMA.

\section{References}

ALVES, LCP. and ANDRIOLO, A., 2005. Camera traps used on the mastofaunal survey of Araras Biological Reserve, IEFRJ. Revista Brasileira de Zoociências, vol. 7, no. 2, p. 231-246.

ANDERSON, CB., ROZZI, R., TORRES-MURA, JC., MCGEHEE, SM., SHERRIFFS, MF., SCHÜTTLER, E. and ROSEMOND AD., 2006. Exotic vertebrate fauna in the remote and pristine sub-Antarctic Cape Horn Achipelago, Chile. Biodiversity and Conservation, vol. 15, no. 1, p. 3295-3313. http://dx.doi.org/10.1007/ s10531-005-0605-y

ARAÚJO, RM., SOUZA, MB. and RUIZ-MIRANDA, CR., 2008. Densidade e tamanho populacional de mamíferos cinegéticos em duas Unidades de Conservação do Estado do Rio de Janeiro, Brasil. Iheringia, Série Zoologia, vol. 98, no. 3, p. 391-396. http:// dx.doi.org/10.1590/S0073-47212008000300014

BARNETT, BD. and RUDD, RL., 1983. Feral dogs of the Galapagos Islands: impact and control. International Journal on Studies on Animal Problems, vol. 4, p. 44-58.

BRASIL. Secretaria do Orçamento e Coordenação da Presidência da República. 1992. Manual técnico da Vegetação Brasileira. Rio de Janeiro: IBGE. 193 p. Série Manuais Técnicos em Geociências.

BUTLER, JRA., DU TOIT, JT. and BINGHAM, J., 2004. Freeranging domestic dogs (Canis familiaris) as predators and prey in rural Zimbabwe: threats of competition and disease to large wild carnivores. Biological and Conservation, vol. 115, no. 3, p. 369-378. http://dx.doi.org/10.1016/S0006-3207(03)00152-6

CASELLI, CB. and SETZ, EZF., 2011. Feeding ecology and activity pattern of black-fronted titi monkeys (Callicebus nigrifrons) in a semideciduous tropical forest of southern Brazil. Primates, vol. 52, no. 4, p. 351-359. PMid:21861115. http://dx.doi.org/10.1007/ s10329-011-0266-2

CUTLER, TL. and SWANN, DE. 1999. Using remote photography in wildlife ecology: a review. Wildlife Society Bulletin, vol. 23, no. 3 , p. 571-581.

ELTON, DK., 1972. The ecology of invasions by animals and plants. London: Chapman \& Hall. 181 p.

ESBÉRARD, CEL. and BERGALLO, HG. 2008. Influência do esforço amostral na riqueza de espécies de morcegos no Sudeste do Brasil. Revista Brasileira de Zoologia, vol. 24, no. 1, p. 67-73.

GALETTI, M. and SAZIMA, I., 2006. Impacto de cães ferais em um fragmento urbano de Floresta Atlântica no sudeste do Brasil. Natureza e Conservação, vol. 4, no. 1, p. 58-63.
HAMMER, AS., DIETZ, HH., ANDERSEN, TH., NIELSEN, L. and BLIXENKRONE-MOELLER, M. 2004. Distemper virus as a cause of central nervous disease and death in badgers (Meles meles) in Denmark. Veterinary Record, vol. 154, no. 17, p. 527-530. PMid:15134165. http://dx.doi.org/10.1136/vr.154.17.527

HOROWITZ, C., 1992. Plano de Manejo do Parque Nacional de Brasília: Avaliação da Metodologia de Planejamento adotada, Execução e Resultados Alcançados no Decênio 79/89. Brasília: Universidade de Brasília. 203 p. Dissertação de Mestrado em Ecologia.

KARANTH, KU. and NICHOLS, JD., 1998. Estimation of tiger densities in Índia using photographic captures and recaptures. Ecology, vol. 79, no. 8, p. 2852-2862. http://dx.doi.org/10.1890/00129658(1998)079[2852:EOTDII]2.0.CO;2

KAYS, RW. and DEWAN, AA., 2004. Ecological impact of inside/outside house cats around a suburban nature preserve. Animal Conservation, vol. 7, p. 273-283. http://dx.doi.org/10.1017/ S1367943004001489

KELLY, MJ., 2008. Design, evaluate, refine: camera trap studies for elusive species. Animal Conseration, vol. 11, p. 182-184. http://dx.doi.org/10.1111/j.1469-1795.2008.00179.x

KELLY, MJ. and HOLUB, EL., 2008. Camera trapping of carnivores: trap success among camera types and across species, and habitat selection by species, on Salt Pond Mountain, Giles Country, Virginia. Northeastern Naturalist, vol. 15, no. 2, p. 249-262. http://dx.doi.org/10.1656/1092-6194(2008)15[249:CT OCTS]2.0.CO;2

KELLY, MJ., NOSS, AJ., DI BITETTI, MS., MAFFEI, L., ARISPE, RL., PAVIOLO, A., DE ANGELO, CD. and DI BLANCO, YE., 2008. Estimating Puma densities from camera trapping across three study sites: Bolivia, Argentina, and Belize. Journal of Mammalogy, vol. 89, no. 2, p. 408-218. http://dx.doi. org/10.1644/06-MAMM-A-424R.1

KRUUK, H. and SNELL, H., 1981. Prey selection by feral dogs from a population of marine iguanas (Amblyrhynchus cristatus). Journal of Applied Ecology, vol. 18, p. 197-204. http://dx.doi. org/10.2307/2402489

LACERDA, ACR., TOMAS, WM. and MARINHO-FILHO, J., 2009. Domestic dogs as an edge effect in the Brasília National Park, Brazil: interactions with native mammals. Animal Conservation, vol. 12, p. 477-487. http://dx.doi.org/10.1111/j.1469-1795.2009.00277.x

LEITÃO-FILHO, HF., 1992. A flora arbórea da Serra do Japi. In MORELLATO, LPC. Historia natural da Serra do Japi: ecologia e preservação de uma área florestal no sudeste do Brasil. Campinas: Editora da Unicamp. p. 40-62.

LEPCZYK, CA., MERTIG, AG. and LIU, J., 2004. Landowners and cat predation across rural-to-urban landscapes. Biological Conservation, vol. 115, p. 191-201. http://dx.doi.org/10.1016/ S0006-3207(03)00107-1

LYRA-JORGE, MC., CIOCHETI, G., PIVELLO, VR. and MEIRELLES, ST., 2008. Comparing methols for sampling large and medium sized mammals: camera traps and track plots. European Journal of Wildlife Research, vol. 54, p. 739-744. http:// dx.doi.org/10.1007/s10344-008-0205-8

MENDES, SL., 2004. Workshop Floresta Atlântica e Campos Sulinos: Grupo de Mamíferos - Documento Preliminar. Available from: <www.bdt.fat.org.br/workshop/mataatlantica/BR/rfinais/ rt_mamiferos>. Access in: 06 Nov. 2008. 
MORELLATO, LPC. and LEITÃO-FILHO, HF., 1992. Padrões de frutificação e dispersão na Serra do Japi. In MORELLATO, LPC. Historia natural da Serra do Japi: ecologia e preservação de uma área florestal no sudeste do Brasil. Campinas: Editora da Unicamp. p. 112-140.

MYERS, N., MITTERMEIER, RA., MITTERMEIER, CG., FONSECA, GAB. and KENT, J., 2000. Biodiversity hotspots for conservation priorities. Nature, vol. 403, p. 853-858. PMid:10706275. http://dx.doi.org/10.1038/35002501

NOWAK, RM., 1999. Walker's mammals of the world. Baltimore: John Hopkins University Press. 1732 p.

O'BRIEN, TG., 2008. On the use of automated cameras to estimate species richness for large-and medium-sized rainforest mammals. Animal Conservation, vol. 11, p. 179-181. http://dx.doi. org/10.1111/j.1469-1795.2008.00178.x

ODELL, EA. and KNIGHT, RL., 2001. Songbird and MediumSized Mammal Communities associated with Exurban Development in Pitkin County, Colorado. Conservation Biology, vol. 15 , no. 4, p. 1143-1150. http://dx.doi.org/10.1046/j.15231739.2001.0150041143.x

OLIVEIRA, TG. and CAVALCANTI, SMC., 2002. Identificação de Predadores de Animais Domésticos. In PITMAN, MRPL., OLIVEIRA, TGR., PAULA, C. and INDRUSIAK, C. Manual de Identificação, Prevenção e Controle de Predação por Carnívoros. Brasília: IBAMA. p. 31-50

OLMOS, F., ALBURQUEQUE, JL., GALETTI, M., MILANO, MS., CAMARA, IG., COIMBRA-FILHO, AF., PACHECO, JF., BAUER, C., PENA, CG., FREITAS, TRO., PIZO, MA. and ALEIXO, A., 2002. Correlação política e biodiversidade: a ameaça das populações tradicionais à Mata Atlântica. In ALBUQUERQUE, JLB., CANDIDO, JF., STRAUBE, FC. and ROODS, EA. Ornitologia e conservação: da ciência às estratégias. Tubarão: UNISUL. p. 279-312.

PINTO, HS., 1992. Clima da Serra do Japi. In MORELLATO, LPC. Historia natural da Serra do Japi: ecologia e preservação de uma área florestal no sudeste do Brasil. Campinas: Editora da UNICAMP. p. 30-38.

PONÇANO, WL., CARNEIRO, CDR., BISTRICHI, CA., ALMEIDA, FFM. and PRANDINI, FL., 1981. Mapa Geomorfológico do Estado de São Paulo. São Paulo: Instituto de Pesquisas Tecnológicas. $94 \mathrm{p}$.

PRADO, MR., ROCHA, EC. and GIUDICE, GML., 2008. Mamíferos de médio e grande porte em um fragmento de Mata Atlântica, Minas Gerais, Brasil. Revista Árvore, vol. 32, no. 4, p. 741-749. http://dx.doi.org/10.1590/S0100-67622008000400016

SANTORO, E. and MACHADO-JÚNIOR, DL. 1992. Elementos de geológicos da Serra do Japi. In MORELLATO, LPC. Historia natural da Serra do Japi: ecologia e preservação de uma área florestal no sudeste do Brasil. Campinas: Editora da UNICAMP. p. 24-29.

SRBEK-ARAÚJO, AC. and CHIARELLO, AG., 2005. Is cameratrapping an efficient method for surveying mammals in Neotropical Forest? A case study in south-eastern Brazil. Journal of Tropical Ecology, vol. 21, no. 1, p. 121-125. http://dx.doi.org/10.1017/ S0266467404001956
-, 2007. Armadilhas fotográficas na amostragem de mamíferos: considerações metodológicas e comparação de equipamentos. Revista Brasileira de Zoologia, Vol. 24, no. 3, p. 647-656. http:// dx.doi.org/10.1590/S0101-81752007000300016

-, 2008. Domestic dogs in Atlantic Forest reserves of southeastern Brazil: a camera trapping study on patterns of entrance and site occupancy rates. Brazilian Journal of Biology, vol. 68, no. 4, p. 771-779 PMid:19197494. http://dx.doi.org/10.1590/ S1519-69842008000400011

SETZER, J., 1966. Atlas Climático e Ecológico do Estado de São Paulo. Comissão Interestadual da Bacia do Paraná-Uruguai em colaboração com as centrais elétricas de SP. São Paulo: (CESP). $61 \mathrm{p}$.

SILVA, LD. and PASSAMANI, M., 2009. Mamíferos de médio e grande porte em fragmentos florestais no município de Lavras, MG. Revista Brasileira de Zoociências, vol. 11, no. 2, p. 37-144.

SILVEIRA, L., JÁCOMO, AT. and DINIZ-FILHO, JA., 2003. Camera trap, line transect census and track surveys: a comparative evaluation. Biological and Conservation, vol. 114, p. 351-355. http://dx.doi.org/10.1016/S0006-3207(03)00063-6

SILVER, SC., OSTRO, LET., MARSH, LK., MAFFEI, L., NOSS, AJ., KELLY, MJ., WALLACE, RB., GÓMEZ, H. and AYALA, G., 2004. The use of camera traps for estimating jaguar Panthera onca abundance and density using capture/recapture analysis. Oryx, vol. 38, no. 2, p. 148-154.

TABARELLI, M., PINTO, LP., SILVA, JMC., HIROTA, MM. and BEDÊ, LC. 2005. Desafios e oportunidades para a conservação da biodiversidade na Mata Atlântica brasileira. Megadiversidade, vol. 1, no. 1, p. 132-138.

TOBLER, MW., CARRILO-PERCASTEGUI, SE., PITMAN, RL., MARES, R. and POWELL, G., 2008. An evaluation of camera traps for inventorying large-and-medium sized terrestrial rainforest mammals. Animal and Conservation, vol. 11, p. 169-178. http:// dx.doi.org/10.1111/j.1469-1795.2008.00169.x

TORRES, PC. and PRADO, PI., 2010. Domestic dogs in a fragmented landscape in the Braazilian Atlantic Forest: abundance, habitat use and caring by owners. Brazilian Journal of Biology, vol. 70, no. 4, p. 987-994. PMid:21180903. http://dx.doi.org/10.1590/ S1519-69842010000500010

TRAVASSOS, L., 2011. Impacto da sobrecaça em populações de mamíferos e suas interações ecológicas nas florestas neotropicais. Oecologia Australis, vol. 15, no. 2, p. 380-411. http://dx.doi. org/10.4257/oeco.2011.1502.14

TROLLE, M., 2003. Mammal survey in the southeastern Pantanal, Brazil. Biodiversity and Conservation, vol. 12, p. 823-836. http:// dx.doi.org/10.1023/A:1022489426920

TROLLE, M. and KERY, M., 2003. Camera-trap study of ocelot and other secretive mammals in the northern Pantanal. Mammalia, vol. 69 , no. $3-4$, p. $405-412$

VELOSO, HP. and GÓES-FILHO, L., 1992. Fitogeografia brasileira: uma classificação fisionômica-ecológica da vegetação neotropical. Salvador: IBGE. 85 p. Boletim Técnico. Projeto Radam Brasil. Série Vegetação.

VOSS, RS. and EMMONS, LH., 1996. Mammalian diversity in Neotropical Lowland Rainforests: a preliminary assessment. Bulletin of the American Museum of Natural History, vol. 230, p. 1-115. 